\title{
THE TRANSMISSION OF KNOWLEDGE AMONG ESTONIAN WITCH DOCTORS
}

\section{Mare Kõiva}

According to a recently developed legend, it so happened that seven of the most famous Estonian witches came together. They discussed various things, spoke about their experiences and finally started to argue who was the most powerful

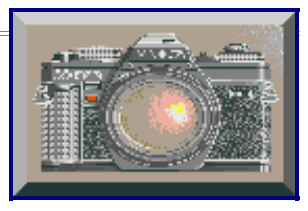
among them. They decided to find it out. A disciple was sent out to fetch anybody from the street. The disciple came back with a woman. According to the agreement, everybody was to try his or her best to say something about the woman. They all watched the woman, but nobody saw anything. They could hardly see the woman. Suddenly one of the witches shouted: "I know who is the most powerful among us! I saw him sending a white cloud between us and the woman!"

This incident (in terms of folklore studies, a legend) is said to have happened a few years ago. There are several variants of the legend at the Estonian Folklore Archives. The reports about some of these seven witches are used in the present paper; however, I have mostly relied on materials recorded in the Võnnu parish and those registered in the files of magic formulas. I would like to emphasize that the article speaks about real people who act as healers or witch doctors.

On the whole, the witch doctors under discussion can be divided in two groups: representatives of traditional rural culture and urban doctors. This is a very obscure division. Here I am relying chiefly on the opinion that the so-called urban doctors are using methods from the alternative medicine of many different nations, their connection with ethno-medicine and traditional culture is relatively weaker, while they can be more closely associated with some definite schools or with the New Age movement. In most cases they are also living in towns or cities, rarely in remote places in the countryside. However, today even the doctors using traditional folk medicine are not untouched by different influences, many of them work hand in hand with an official physician and use different possibilities of formal medicine.

The first part of this article is an attempt to define, who are chosen by the traditional witch doctors and who by modern healers to inherit their knowledge. In the following paragraphs we shall see when and under which circumstances the transmission takes place. Traditional knowledge is inseparable from certain canons of the tradition, from the prescriptions that are to be observed, to ensure success of the process. Often the healing rites are connected with temporal and spatial parameters that are to be taken into account, although in some cases there can be some concessions. The article refers to the cases where the healer reckons with traditional canons, and still has a certain degree of freedom to shape the rite according to his or her own will. 


\section{Persons to Whom Traditional Healers Transmit Their Knowledge}

Võnnu is a parish in the Tartu district, relatively big according to Estonian standards, covered with marshes and forests, where around 700 folk healers have worked during the past hundred years. About 350 of them were women and the rest were men. Traditional medicine ceased to be used in the $60 \mathrm{~s}$ and $70 \mathrm{~s}$ of this century, but some representatives of the former witch dynasties applied their knowledge for healing as late as in 1986 when field work was undertaken there. Already in the early 1960s the then young folklore collector Mall Hiiemäe came across two aged local witch doctors, and the material from the 80 s offers interesting information about the further fate of the esoteric tradition of these families. I shall call one of these families (Ida Poska's) witch A, and the other (Emilie Vuks's) witch B. The other witches living in the same or neighbouring villages shall be witches C, D, E, F, G, H.

According to beliefs, a witch doctor could transmit his/her knowledge only once, according to some reports only three times, otherwise he/she was said to lose the power of healing. Actually, the knowledge was transmitted on several occasions. The belief that knowledge cannot be transmitted more than once, otherwise the healer loses his/her power, is very wide-spread, and here I shall quote only a few sources (Mansikka 1927; Pócs 1985; Hoffmann-Krayer \& Bächtold-Stäubli 1930/1:1893 -1894, Peskov 1980:251). Quite the opposite is the case when spells are transmitted to the patient, which happens fairly easily, and the holder of the spell has no fear of losing his/her power. Thus have proceeded several Estonian witch doctors, as well as some healers in the Estonian settlements in Siberia (Korb \& Peebo 1995:21). The so-called protection and heavenly letters that contain, among other things, several protective and healing spells as well as letter formulas, include also an explicit command to copy the text and distribute it among fellow sufferers. The situation where simple healing spells and charms of promoting household are known to nearly every adult inhabitant in the village was referred to in my research into spells (Kõiva 1990:146). Similar free distribution and wide circulation of esoteric verbal magic has been brought up by other researchers (Smirnov 1988:53). Identical ideas are represented even in remote cultures. D. R. Price-Williams writes, that 'in practice anybody can set himself up as such a practitioner and rationalize the position' (Price-Williams 1973:364). There have just been very few of those who have deeper knowledge of diseases and their cure, and who thus can heal many of them.

In Estonia the position of folk healers was not considered to be of any merit even in the present century. Folklorists preferred to collect their spells, i.e. concrete texts. These texts of magical spells are without any comments and out of context; often there is no specification of the situation when they were presented. Occasional descriptions of transmission, belonging to the general background or context, were overlooked in such text-oriented collection. The institution of folk healers, their life, philosophy, and world outlook were never subjects of inquiry or recording. The attitude towards them was often that of fear and prejudice, they were regarded as almost half-mythical beings. Folklore narratives about healers were identified with their actual personal features. They were regarded with mistrust. Moreover, even the witch doctors themselves could be haughty or cross, deny their practice and refuse to discuss it. This has been reflected in several fieldwork diaries in the Estonian Folklore Archives. Partly, people have tried to avoid groundless curiosity, but there have been several reasons to their disobliging. 
In the mid-1980s when a specified inquiry was carried out, traditional folk medicine was already in decline. Often, informants were grandchildren of the former witch doctors. In most cases, they had declined to accept the heritage, they had never taken interest in their parents' knowledge or taken pains to memorize their healing methods. There were also distant relatives and other informants who had come in touch with healers, had been their patients or lived in their neighbourhood; some just remembered what their parents had told about their experience with witch knowledge and their contacts with such people. Even the latest and scantiest information has shown that knowledge was transmitted by very different channels.

Witch A (Ida, a well-known midwife and rose-healer) began to heal people as a young woman. Her husband could also cure diseases (snake-bite, etc.). They also exchanged their knowledge. According to folk belief, Ida and her husband knew snake spells, too. Ida received spells and healing instruction from a local elderly male witch doctor, whose name and family are obscure. The only established fact is that he lived in a neighbouring large village. Ida had a family: two sons and a daughter, of whom two have taken up healing after her. In 1986 the children were elderly people. Witch A transmitted her knowledge to her two sons, a daughter, a passer-by, and to the Folklore Archives. Two of her successors act as witch doctors, the daughter is well known in the neighbouring villages and people seek her help when humans or animals fall ill.

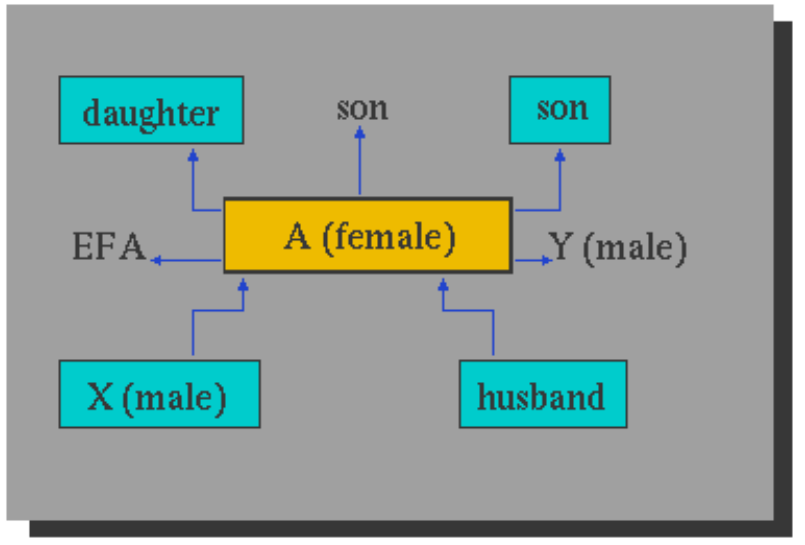

Figure No 1. A box is drawn around witches and their successors who have acted as doctors.
Witch A was considered to be a good midwife, and people have come from faraway places with horses to fetch her. Part of her knowledge she gained from her husband: 'Ida's husband' when he whistled, snakes would come to his house as if it were raining of them. He also knew the charm and the whistle, the way he whistled, and the snakes went there. /---/' (RKM II 395, 360 (4) < Võnnu parish, Savimäe village - Mall Hiiemäe < Milda Anijärv, 63 a. (1986)).

One of Ida's sons became a local folk healer specializing in ring-bone and other not so serious diseases. Her other son claims that he

was considered without talent by the family, he was the youngest child and therefore he was not taken into account. Though he has noted several things during the healing procedures. He himself does not heal people.

The best known of the children is the daughter Linda, known as Linda of Poska. Local people know her also by the name of her first husband as Prunni Linda, or by the family name of her last husband, Käämbre Linda. She is presently residing in the neighbouring parish. Her daughter, also known as a witch, continues to use her father's knowledge, which she however did not learn directly from her father, but from her mother. The daughter uses incantations for healing. Methods of healing erysipelas (rose), ear-ache, and other diseases are typical to traditional medicine: fat with incantations, notebook cover rubbed with pencil graphite. She also heals other diseases with which people come to her, including external tumours ("Made several circles around it with a knife. With a table-knife - and afterwards gently with her own finger, too') and different skin diseases or the so- 
called diseases from the earth. She is also known for curing ring-bone on horses and people, so that some are said to call her a ring-bone-healer. These diseases she also treats with methods that belong to the classics of folk medicine, such as restricting the foci with things made of iron; she prefers, however, to use washing the disease off with moonlight.

In her lifetime Ida was displeased with her daughter's success and often reproached her for being preferred by patients (RKM II 395, 361 (6) < Võnnu parish - Mall Hiiemäe < Milda Anijärv, 63 a. (1986)). Her relations with other witch doctors in the neighbourhood were said to be good. However, there is no evidence about any exchange of spells or knowledge between them. It is possible that they merely communicated with each other on an everyday level, but, even more likely, the archive records (including the supplementary questionnaire) are not so thorough as to give any substantial proof to the spread of such secret tradition.

Belief accounts assure that she was considered a healer, a good person. Despite that she was still thought to possess a book of black magic with which you can intentionally cause evil to people. The last opinion indicates that even the most good-hearted healers are still suspected of an ability to cause evil. The belief that witches can cause chaos and diseases is widespread, and the opinion that witches are a destructive and anti-social power has been upheld by the church (Alver \& Selberg 1987: 26).

Witch B (Emilie) transmitted her knowledge to her daughters, to a granddaughter and to the Folklore Archives. In this family there are no acting witch doctors, although one of them, who inherited the written magic formulas and the complete knowledge, is considered to possess an evil eye. The same was said about her mother. As village people say, she could communicate with birds and animals, but regardless of her high ethical principles she was regarded as a dangerous person in the village.

In 1965, Mall Hiiemäe (to whom the old witch doctor recited the healing spells) wrote in her fieldwork diary that the elder daughter had no faith in her mother's spells. After twenty years, the daughter could still repeat the spell against erysipelas that had been written down on a piece of paper, as well as other spells, and she remembered her mother's

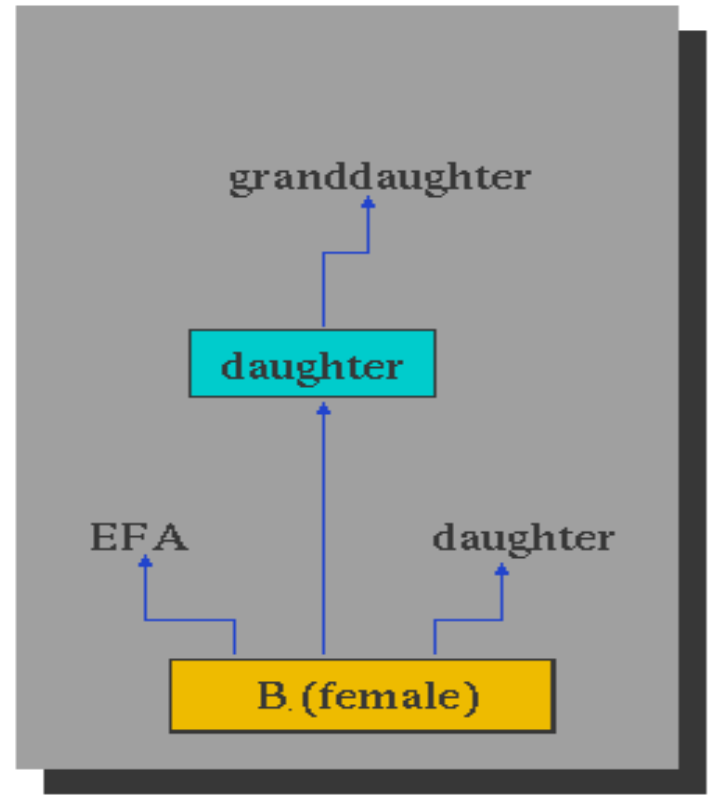

Figure No 2. A box is drawn around witches and their successors who have acted as doctors. healing methods and the ointments she used to prepare. She even remembered the ceremonial action that accompanied the recitation: '(---) The curing was like that: you had to say it in one breath, and you had to draw circles with a grey pencil without a stop. The paper had to be thick - something like a sheet from a notebook or its cover. She drew circles on it and made some obscure crosses and recited the spell over it.' 
The most precise account of the transmission is given by the daughter who inherited the written spells from her mother: 'She gave me the words and said that you had to say them three times during the wedding ceremony. First you learned them by heart. But did I ever learn them! I did not, and I never used them.' (RKM II 395, 337/40 (1) < Võnnu parish, Savimäe village - M. Hiiemäe < Lehte Lokk (1986)). Accepting of the trade is also commented by the other daughter: 'Mother wanted to pass it over to me, but I did not believe it, and there it was'. The granddaughter justifies her refusal with her young age: 'I was young and full of arrogance - what were such old beliefs to me!'.

In the same village lived a third witch doctor, witch $\mathrm{C}$ (Alma), who acquired her knowledge from her brother-in-law (E), who also knew of snake spells. Part of her knowledge she learned from an Estonian from Russia who lived in the neighbourhood, having settled in the village during the war $(\mathrm{G})$, and from another man in the village who knew snake spells (D). Alma had no disciples, and she could not pass on her knowledge within her family, and so she has recently used her skills mainly for her family in the case of necessity.

Witch D (Karl) knew spells to cure snake-bites, and some of his art he transmitted to his wife and daughter, but they never succeeded him in the trade. Karl's knowledge came from several local older witch doctors and, partly, from literature.

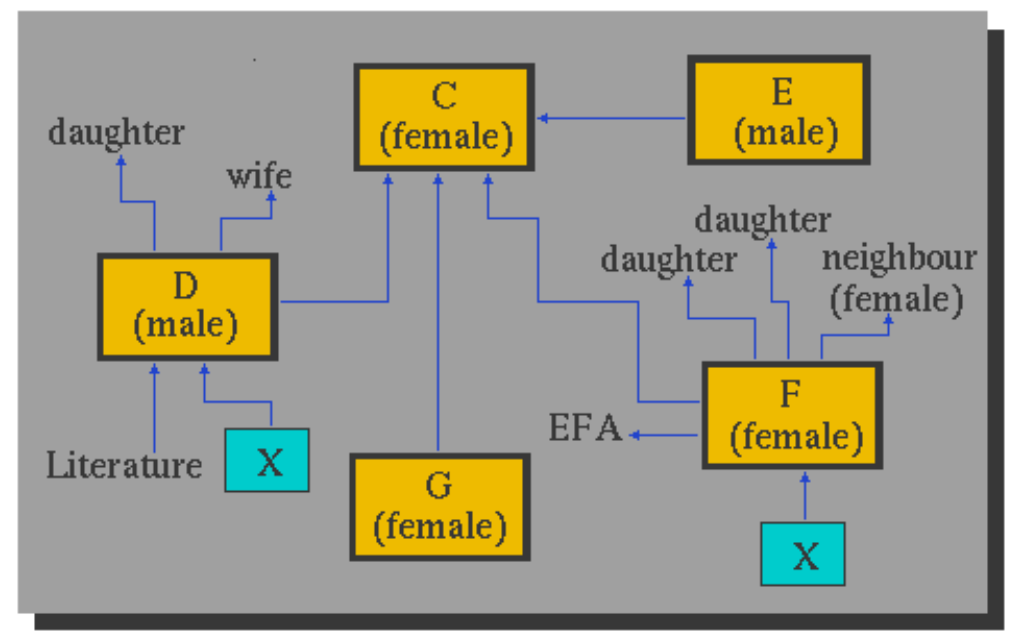

Figure No 3. $A$ box is drawn around witches and their successors who have acted as doctors.
The source of knowledge of witch E (Ziuga) is not known. His disciples were Alma (C) and to a certain extent Solna $(G)$, the Estonian from Russia.

Witch F (Luise) came from a colonial community, she brought her knowledge from there and acquired it also from Solna, the Estonian from Russia. She was known in the neighbourhood as a potion mixer and a healer of snake-bites: 'Luise recited her spells over vodka, and the vodka had a musty stench. She recited it over a child, and the child stank, too.' (RKM

II 397, 226 (23) < Võnnu parish - K. Peebo < Emma Märtson, 98 a. (1986). In her old age she lived in Tartu, and she did not use her spells or healing knowledge. Part of her lore is kept at the Estonian Folklore Archives. Eda Kalmre describes her in the fieldwork diary: 'She knew how to treat illnesses caught from snakes, dogs, cows, how to heal creaking joints (inflammation of carpal joints), fire signs, etc., and she believed in them.' (RKM II 397, 597/8 < Tartu - E. Kalmre (1986).

Most of what was connected with folk medicine in the practice of witch G (Solna) came also from a colonial settlement in Russia, from the Estonian and Russian tradition that existed there. She instructed healers $\mathrm{C}$ and $\mathrm{D}$, her two daughters, and at least one neighbouring woman. There are 
quite a few fragmentary data about Solna's healing methods. She treated injuries, erysipelas, snakebites, various infant diseases, and various ills caused by the evil eye. She also cured domestic animals. An inseparable part of her séance was spell-casting. Usually she recited her spells over unsalted pork fat or other traditional substances. Local inhabitants have described her as a good specialist in herbal remedy. One of the daughters remembered her mother's healing methods, the other had repeatedly written down magic spells, but had later lost them or thrown them away. She justified her lack of interest in mother's healing methods with her allegedly poor memory.

Witch H (Marie) got her knowledge of healing from an old woman who lived in the same village and who could cure various diseases. She never used the knowledge herself. All that she remembered she presented to the Archives.

As the brief list above shows, the transmission of knowledge has by no means been easy in the 20th century, because the inheritors were not interested in traditional lore. I have described the reasons for such attitudes in a previous article (Kõiva 1995:224), and therefore I shall not dwell on the subject. The main reasons for rejecting the healer's trade seem to have been changes in the way of life and the falling prestige of traditional medicine. In a village community the reason may also have been the wish to be free from the status of a witch and from the attending attitudes and preconceived ideas.

\section{Contemporary Folk Healers and Transmission}

I do not know whether the 1970s were a more difficult period for witch doctors than, say, the era of political oppression in the 1940s and 50s. In spite of the official hostility towards popular and alternative ways of healing, witch doctors were highly esteemed by their patients. People came to visit them alone, or with their whole families and friends. Sometimes they even rented a bus and whole groups of colleagues and sympathizers drove to the other end of Estonia to see such people. Contemporary healers differ from each other in their social background and education more than the mediators of the previous century or the early 20th century who applied methods of traditional folk medicine. Then the healers were farmers, smallholders, craftsmen, even some parsons, parish clerks, officials of manor and township administrations, landowners, etc. Still, most of the healers were inferior farmers.

Let us here say a few words about some of the witch doctors that featured in the legend at the beginning of the article. We have chosen the most typical representatives of witch doctors with different backgrounds and healing methods.

Gunnar Aarma (born 1916) is a music teacher, a university graduate, member of Lutheran church. On several occasions he has embraced Islam and extracted medical knowledge from Islamic philosophy and medicine. In Estonia he is justly regarded the grand old man, guru and promoter of Buddhism. For years he has propagated Eastern medicine and its methods. He makes use of acupuncture and acupressure, diagnoses afflictions with the help of eyes, ears and soles of feet. One 
of his healing methods is gong therapy; he has studied and experimented on music therapy, diagnosed with a pendulum, advocates hunger cures and hydropathy, etc. Both of his grandmothers were village healers whose methods Aarma has described as intuitive and, therefore, of little interest to him. Anyway, he has seen them healing and massaging. During his years of banishment and prison camps he has met several Russian witch doctors. At that period he also came into contact with a Yakut shaman. He may be considered one of the first importers and brokers of mumio in Estonia. Very innovative were his séances of hunger cure and the promotion of macrobiotic diet. As for herbs and diet, Aarma has always stressed the necessity to choose from those that grow near one's place of living - only these can sustain your health.

In one of my previous articles I have referred to the substantial influence his manuscript books have exerted, how these were passed on from hand to hand and copied (Kõiva 1995:222). By now, several of them have been published (e.g. Aarma 1995, 1996), and there have also been interviews in books (Mirtem 1994) and media. I should characterize him as a philosopher, in a way, a witch doctor whose healing séances are notably spiritual, who spends his time and energy trying to shape the philosophy and attitudes of his patients. At the same time, his own personality, his life and the elucidation of its complicated moments, his own experience seem to be an inseparable part of his healing séances. People that come to see him are stimulated with a discourse about difficult situations. His wife and three children respect and support Gunnar Aarma's ideology and esoteric practices. Heljo Aarma often accompanies her husband on lectures and is his closest assistant at receptions. Their daughter Maria has tried to interpret traditional material, taking as her starting point the identical principles (such as 'Mother Earth Fair'). Through his books, Aarma is a teacher of many physicians and folk healers. From the most prominent witch doctors he has been in closer relationship with, and given instruction to Vigala Sass and Lille Lindmäe, but there have been others. It is not easy to ascertain the exact number of his disciples, since many people have paid brief visits and talked to him. It is clear, however, that Aarma does not consider them as his disciples.

Aleksander Heintalu or, as he is known, Vigala Sass (born 1941) is a university graduate and has taken his $\mathrm{PhD}$ in agronomy. His widespread diagnosing and healing activities begun in the 1970s and for decades already he has been the best known witch doctor of Estonia. Vigala Sass grew up in an orphanage and worked hard to obtain education and to improve his accomplishments. He if anyone has been encouraged by post-war difficulties, as he grew without a family to develop abilities that usually lie dormant in children that are raised in a safe family atmosphere. To test his abilities, he has observed paranormal phenomena, experimented and explored. Part of the information he gained this way, he added to his methods of diagnosing and healing. Vigala Sass is a herbalist. He not only gathers medicinal herbs, heals with them, and prepares potions, but also grows and imports various medicinal herbs from abroad. From his expeditions to the mountain and desert areas of the former Soviet Union he has brought them along to be planted at his experimental fields. He grows exotic herbs, crossbreeds them and mixes into his potions. In his doctoral thesis he analysed the use of Rodiola in veterinary medicine (Heintalu), presuming that it had excellent perspective in economy. He was undoubtedly one of the first promoters of Rodiola and mumio. In addition to his so-called "sounding" of medicinal herbs and diseases, he has applied various healing methods, incl. massage, acupuncture and acupressure, hypnosis. Besides his frequent appearances in mass media, he has authored several books that describe his healing methods (Vigala Sass 1992; 1996). His books are anthologies where personal experiences are combined with knowledge obtained from books, personal empirical observations mixed with astrology and a glimpse of oriental medicine. The astrological component is, as he says, a compromise with modern trends and expectations of the readers. 
In his development years, and afterwards, he has come into contact with other witch doctors and people devoted to the study of paranormal phenomena. His abilities intrigued some research centres in Russia and, allegedly, to the security committee. Moreover, on his expeditions he also used to find out and pay visits to local healers and exchange information with them. From people who supported Vigala Sass and with whom he associated in the 1970s, I would like to mention Meeme Karolin, an enthusiastic lecturer and modeller and user of miscellaneous devices for the examination of unusual phenomena. He has been one of the mediators of Russian literature of paranormal phenomena to the southern Estonian reader. For decades already, he has surrounded himself with psychics, measurers of the earth's energy, dowsers and healers. His circle of friends has changed: different people have belonged to it for a shorter or longer period of time (usually they have been related with the Estonian Agricultural Academy, with the city of Tartu or with southern Estonia).

In addition to Gunnar Aarma, Vigala Sass has visited such well-known Estonian folk healers as Laine Roht and H. Lilleste. Sass' son has grown up and learned esoteric knowledge from his father. The talented young man is expected to take over his father's trade in herbal remedy. Some things he has also taught to his stepson Ivo and to his numerous temporary disciples and students, among them secondary school graduates, university students of different specialities, medics, men of arts and sciences. His meetings with choirs (Vigala Sass is a choir veteran), librarians, participants in various training courses are by now a tradition. The most enduring ties of the past ten years link him with the heathenist movement. Among them Sass has found disciples who are very eager to learn from him. Young heathens have helped Sass to build his place of worship where he conducts most of his rites, and participated in his incantation rites, some of which (e.g. the autumn incantation of 1992) have been specially dedicated to them.

Vigala Sass has a peculiar way of interpreting Estonian mythology and formulating the individual religion; he is the first and foremost neo-shaman (cf. Kõiva 1995: 231; Hoppál 1996). In addition to Estonian mythology, his philosophy is inspired by the Karelian-Finnish epic Kalevala. His interpretations and etymologies are unique: a mixture of what he has picked up from books, conversations, and inspiration. These are products of independent thought that only partly overlap with academic versions of mythology. Folklore material, as well as books and articles have been given to Sass - or copied or procured, for that matter - by his friends and associates. At that, the Balto-Finnic heritage and literature is not the sole source of information: he has communicated with Nganasan and Altai shamans. He, like Gunnar Aarma, has expressed his opinion that only part of the knowledge that is based on intuition and traditional world view can be applied in healing practice.

Laine Roht or Kaika Laine, known also as the Witch of Kaika (born 1927) comes from a family that has brought forth several folk healers, but also formal doctors of remedy. Her great-grandmother and father were witch doctors. 'My father knew how to massage and cure animal diseases. Strangles and sprains on horses were cured by him. And he delivered calves. He had a gadget with which he could sound animals. He was called when someone had sprained an ankle or something. His main remedies were turpentine, spirits of wine, neat's-foot oil. Our great-grandmother (grandfather's mother) also knew how to heal. She delivered babies.'

Laine has primary (6-year) education. She was born with the so-called sign of a doctor: as the midwife maintains, at birth she had the sign like a cross, a cup of poison and a snake on her forehead. In her development years, besides her midwife, she had personal contacts with a witch doctor who lived near Sangaste and with Marta Hamer, an elderly healer and soothsayer near Põlva. She began to heal people when she was 33, and her healing methods belong to the routine of the 
traditional folk medicine. In most cases she recites her prayers and spells over remedies, but in the recent years she has taught her patients to use the method of acupressure when applying an ointment to the skin. This she has learned from other healers. Her spells she also found from the volume of magical spells of the Anthology of Estonian Folk Songs, a tip she got from a good acquaintance. Laine has been in friendly relations with several witch doctors during her practice, she has also had disciples, some of whom have co-operated with her for some time. She has received patients in cooperation with a man who in the nearest town was known as a pendulum diagnostician and who later became an independent healer. In the latest years one of her constant associates has been a lecturer from Tartu University, a man of degree. Her relations with other witch doctors and disciples have been unsteady: besides those with whom she has maintained mutual affection for a long time, there are those towards whom she develops resentment and (mutual) distrust in the course of their apprenticeship. Laine has no children, and her brothers, sisters or their children have had no ambition to become healers.

Bookish knowledge, philosophical ideas and practical tips that have been found in books have exercised tremendous influence on contemporary witch doctors. This undoubtedly applied also to the healers of the previous century and of the beginning of this century. At this point I should like to mention again Tiitsu Seiu who besides publications on herbal remedy and esoteric and magical teachings was also very fond of chemistry books and the like. He subscribed for periodicals and books in many languages (Kõiva 1989:92). Today there is a wide variety of esoteric literature of different origin to choose between; the reading languages have also changed. In the 1970s and 80s manuscript translations from English, German and Russian circulated. Along with Estonian translations people began to read Russian. Very typical of the $80 \mathrm{~s}$ was focusing on oriental medicine and philosophy. It was not before the 90s that opportunities emerged to study in China and other centres of oriental medicine. On the other hand, the $80 \mathrm{~s}$ are probably the most Russianbiased decade. Oriental medicine came to be known mostly through the mediation practised in the Russian language. Russian training centres trained Estonians, too. Russian publications circulated in the greatest numbers. In the 70s original treatises by Estonian witch doctors were often passed from hand to hand. A new phenomenon in the publication of esoteric teachings of witch doctors were compilations (Paju 1995), guidebooks (Aarma 1996; Vigala Sass 1992) or original works. I would like to stress the role of original literature. The first books by well-known psychics and folk healers that were published in the 90 s were bought and read by many. Differentiation is only a recent phenomenon and now such material is oriented only to a close circle of sympathizers. Remarkably great is the popularity of Luule Viilma's The Teaching of Survival (Viilma 1996) and The Teaching of Living (Viilma 1994). Luule Viilma, a gynaecologist by profession, has been in the alternative medicine since the late 1980s. Her real fame was brought by her books that are cherished by people of different occupations. She is equally popular among unread people and top intellectuals. In essence, her teaching is akin to Christian moral code and the teaching of forgiveness, combined with the healer's personal views to form an integral whole. The book describes typical situations, claiming that diseases originate in people's depravity, wrong way of thinking, and that they can be removed by forgiveness. Just forgive - and all afflictions, even malignant tumours, are eliminated that is Luule Viilma's teaching.

The Viilma phenomenon is remarkable in that for the first time Estonian psychics and admirers of esoteric teachings have a Master. Namely, an impressive number of doctors of alternative medicine repeat (sometimes in modified form) her principles, and they even use her typical expressions. Very interesting was my recent encounter with a church officer, a former nurse, who, although not quite 
agreeing with Viilma's teachings, quoted the principles from her book. She described how she asked for forgiveness from her aching hands, or from her skin rash, and how all that helps her recover.

Teachings and traditional methods of healing of other nations have penetrated into original literature. Such conglomeration of different cultural traditions is equally characteristic of the physician's ideas of herbal remedy and of the healing books of witch doctors.

I shall leave aside witch doctors of other nationalities, because their circle of patients and practice has not been studied closely; I shall also omit the question how many non-Estonians ever visit an Estonian witch doctor. But quite a new phenomenon are witch doctors who have been trained abroad. In the 1980s they subscribed for courses and studies at psychic schools in Moscow, Kiev and other large cities of Russia. In the 1990s came short and rush courses, and those who had gone through one of such courses got a licence or certificate. Primary courses were organized by Estonians who live abroad and they were greeted with public attention and media coverage. Classes of transcendental meditation were opposed by outstanding witch doctors in TV and radio broadcasts. Healing instructions of different schools were introduced from Scandinavia and (especially) Finland. New healers emerged from people who had gone through some courses, although most of them never go beyond the circle of their closest relatives.

\section{Friends and Strangers}

Naturally, the tradition of the healers is transmitted not only in a family of witch doctors or esoteric environment, but it is constantly supplemented by new knowledge and new talented people from outside. And yet, children who have grown up in the families of certain healers have more prerequisite qualities to become heirs to the lineage of certain esoteric knowledge. A healer acquires most of his/her knowledge from his/her predecessor in the course of direct oral communication, and yet, wisdom accumulates in other ways as well: new information is acquired through dreams, "found" at moments of inspiration, etc. A healer as a bearer of tradition mediates the cultural pattern of his era, realizes the traditionally accepted models, solutions, beliefs and narratives. The internal norms of tradition shape personal experiences and interpretations into a traditionally acceptable, that is to say, standardized form.

The rules and regulations imposed inside an esoteric group are often different from those imposed on ordinary people. The personality of the healer and everything connected with his/her knowledge is mythologized to a certain extent, as is that which is connected with the transmission of healing practices and charms. Although knowledge can be transmitted to an occasional visitor or a patient, such information never spreads very widely, and the event itself was never generalized into popular tradition. These were exceptions known only to the giver and the recipient.

There have been no professional witchcraft schools in Estonia. In most cases, the knowledge of a healer has been transmitted within one's family, although among the disciples there have been some occasional acquaintances, patients, wandering witch apprentices, etc. 
Contemporary witch doctors come into contact with each other on various forums. The greatest and most popular of its kind is Maaema mess (Mother Earth Fair). Besides well-known healers and anthroposophists who showed up at three fairs that have taken place so far, numerous freshman healers and devotees were also present. There they have the opportunity to get acquainted, to exchange their views and just to have a chat. In my view lobby work is an important part of the fair. It is a kind of nursery of contemporary witch doctors where one can find books, music, remedies, and knowledge. But the main thing is the opportunity of communication and meeting with people who share your views. On the fairs the audience can partake in lectures, beginners can meet eminent healers. In the recent years they have tried to launch the Society of Natural Cure which would unite the leading witch doctors and specialists in aroma and colour therapy (both have been introduced recently), as well as agents or foreign companies that produce natural remedies, and, naturally, adherents.

The initial legend indicates a meeting in a friendly atmosphere. There is nothing uncommon in the custom of visiting each other, either to celebrate something, to spend holidays, to exchange information, or for some other reasons. Sometimes the incidents at these meetings develop into traditional accounts. Here is an example:

Well, we were inside, me and my husband. And see, two cars drove up to the threshing-barn. And he went to look who they were. And he came back and said, There are Mrs. Helgi Lilleste, and a gentleman with him, Mr. Tiik, what's his name - the acupuncturist. I don't remember his name. There were two gentlemen and four ladies. And they stayed overnight. We had fire-wood up there behind the barn. They took some wood with them and went up that hill and made a fire there. Suddenly they saw a church in the fire, and people going to that church. Helgi came then running here - we had a fence around the house then - and shouted, come and look.

It had lasted for fifteen minutes. And then came another sight, of horses dancing in the paddock. Well! Next morning they all came down and told us what they had seen on the hill. And asked, if we knew it or had seen it. But, of course, I had not, I knew nothing of that hill. Perhaps our ancestors knew it and saw it.

Co-operation between witch doctors is also suggested in the data about traditional medicine. It is not easy to determine the solidity of such ties, or whether it was the healer who referred the patient to his colleague, or whether it was the patient who went to see several witch doctors. Neither is it unambiguously clear, what were the criteria of choosing a witch doctor, and to what extent it depended on views and convictions that spread in the patient's social group. It is much easier to observe mutual co-operation between the so-called new healers.

Besides the Master -disciple relationship we may come across co-operation between equals or differently specialized healers. This is based on permanent (professional) ties and distribution of tasks. I would like to mention as an example the co-operation between two northern Estonian healers: Veeliks Jalakas (releases people from the so-called bio-vampires) and a female witch doctor, living at Roiu, who prescribes and prepares remedies. The patient gets full-scale treatment from such co-operation. (Veeliks Jalakas has young apprentices, but the relationship between them 
is an ordinary Master -disciple one. The older and more experienced party teaches healing methods, helps to analyse the situation and diagnose the patient's affliction, etc.) Under this group I would classify cases when the other party is entrusted with an important part of the healing process. For example, a trusted associate gathers and dries medicinal herbs for Laine Roht. Such is also the relationship with a colleague who assists the healer in diagnosing, or even in preparing the remedy, when the mediator is tired or requires help. In my opinion this is a gesture of absolute trust. Patients are referred to other specialists when needed by almost all prominent healers. G. Aarma refers his patients who in his opinion need a different treatment to his colleagues: for example, to Tiik when they need acupuncture.

The status of the disciple has also changed. Since the position of a witch doctor is reputable and rewarding, it seems that nowadays the aspirants are sometimes tempted by the financial side of the trade. Disciples begin to heal early in their apprenticeship, with but few experience, and their own disciples and devotees gather around them. That financial interest nourishes their ambitions to become healers is by no means unique. Bente Alver mentioned it in her African study (Alver 1990: 127). Another question is whether it is customary in Europe or typical only to a society in an unstable stage of transition. In urban environment it is more common for immature apprentices to begin to heal. In a traditional culture witch doctors and their doings are regulated by social control which in the cities is not present, or is weaker. Apprentices are also encouraged to begin to heal by the attention given to them in mass media. Series of articles force journalists to find new, unknown witch doctors. So public attention comes upon apprentices before they are quite mature as healers, as well as upon people for whom this is an easy opportunity of self-realization and publicity. Such "promoters" were, for example, the weekly interviews with witches that ran in Liivimaa Kuller for a year. Long programmes on the radio and television at prime time are in my opinion also conducive to such occurrences.

The relations between Masters and their apprentices and disciples have also changed. Almost all known healers have disciples who may stay with them for longer or shorter periods. This is not different from traditional folk medicine. However, a considerable part of disciples are not interested (at least not in the first place) in the healer's trade, but rather in the study of their world outlook, philosophy (such is evidently the relationship between Vigala Sass and neo-heathens) or they are curious to learn esoteric things. Very interesting is also the system of the so-called props that comprises disciples, friends and acquaintances. They exchange and track publications, translate books, copy or just jot down required information or material from books, manuscripts, or archives. In the course of mutual communication information is exchanged in both directions. In this process the witch doctor has the freedom to interpret (and to create a mythology).

Magic formulas and healing skills have been taught to occasional patients who have been considered to possess healing potential. An informant from Võnnu describes a patient's surprise at that: "Some fifteen years ago Sikakurmus's wife had taught him. She said: "I need not come to heal. I'll teach you how to do it." He said: "Come, I cannot do it myself."" RKM II 395, 366 (1) < Võnnu). Finally he did what he was instructed to do and cured himself. Afterwards, he helped his family and friends at need. Such a description is not an exception but rather a case confirming the rule. Although, as we have mentioned, such cases seldom developed into belief accounts, and if they did, then mostly through family tradition, and were not generalized into folk belief. Ida Poska (witch A) has also taught some skills to a wandering village boy who happened to stay in her family. More often, however, it were the wandering witch disciples who were taught: they would 
stay for a while, observe the process of healing and sometimes also add what they knew about methods of healing, knowledge of herbs, magic formulas and what they had read, etc. So, visiting others with the conscious aim of learning from them was a common practice in earlier times, too. Tiitsu Seiu of Saaremaa describes his contacts with a ohatleja (a witch doctor mainly specialized in skin diseases) who lived nearby, his trip to the isle of Muhu and his meetings with the witches of Sõrve, or võlu, as they are called there. He went to the witches of Muhu, among other things, with the request to tell him whether there was any hidden gold on his farm-land. It was mentioned above that the healer of skin diseases was the very person who served as an example for Seiu in creating his healing rite. There were several witch doctors in the nearby villages who worked at the same time as he did. Although there is no detailed information about his visits to them in the Estonian Folklore Archives, there had to be contacts between them, even if only because of the short distance. There was (and is) also nothing unusual in going to see one's colleague because of one's health or other practical problems (such as regaining lost things or fortune-telling), when one's own healing procedures, or those undertaken by one's family, were not considered efficacious (Kõiva 1989: 94).

A part of the knowledge was inherited in a written form (either as an ancient manuscript book of witchcraft, or the candidate was told to write down spells and other traditional methods). They also made additional remarks in the witchcraft manuscripts during their lives. These Estonian manuscripts were influenced by various printed material as well as by magical and other formulas that circulated in Europe in written form. The Estonian Folklore Archives store several of such manuscript witch books. The heritage of Serva Ellu, a witch doctor from Kolga-Jaani has been described by the folklorist Ellen Liiv in her fieldwork diary: 'A transcript from Maali Sahk's notebook where she has written from Serva Ellu's magical spells. Ell has freely recited and taught her spells to others. Maali says, that the spells have been written down over many years, when they just happened to talk about these things. The notebook bears traces of frequent usage. Several paragraphs are illegible'. (RKM II 289, $449<$ Kolga-Jaani parish, Leie village - E. Liiv < Maali Sahk, 71 (1971)). The very tradition of keeping written records is very old, and there is evidence of it in many parts of Europe (see: Rørbye 1983: 90 ff., Tolstaya 1988).

\section{The Evolution of a Healing Rite}

A traditional healer acquires most of his/her knowledge from his/her predecessor in the course of direct oral communication; wisdom accumulates in other ways as well: new information is acquired through dreams, "found" at the moments of inspiration, etc. Obtaining knowledge in dreams has not been mentioned much, although it is present in the tradition of most peoples (for example, it is described by Bente Alver, who finds parallels to Norwegian cases in African tradition (Alver 1990:128). The earliest Estonian records date back to the minutes of witch trials. In 1632 it was reported of a certain Pudell of Kanepi parish, southern Estonia, that an old grey man taught him witchcraft in a dream (Ariste 1936:9). In later times such information has not been specially asked, and therefore the facts are sporadic. 
A healer as a bearer of tradition mediates the cultural pattern of his epoch, realizes the traditionally accepted models, solutions, beliefs and narratives. The internal norms of the tradition shape personal experiences and interpretations into a traditionally acceptable, that is to say a standardized, form.

The custom to go and check out what a person, famous for his/her skills actually knows and does, has been there for centuries. In this century a healer's disciple would often stay for weeks in the Master's family helping in work or acting as an immediate assistant. In addition to beginners, experienced witch doctors also used to exchange their knowledge. Particularly sought were those who knew words of power or had some brand new knowledge. People of equal skills and powers used to visit each other to exchange skills. Setting up contacts depended on many different factors. As a rule, a talented disciple or colleague with a matching character was never denied knowledge.

Esoteric knowledge possessed exclusively by healers is often reshaped by the family according to their ideas. This concerns especially the rite of performance with its details. In addition to the empirical and experiential, a considerable amount of loans from the typical official rites with relevant semantic fields, that is, from the traditional stereotypes, are used.

Undoubtedly the church ceremonies and rites, sermons and church services have had their influence on healing rites and magic chants. Often, they unintentionally carry out in practice what they have seen and experienced earlier. For example, Tiitsu Seiu (1873 -1950) from Saaremaa describes how he created his healing rite: I began to take off my hat when reciting these spells over erysipelas and snake-bites. /---/ After the first time I began to draw three circles counter-clockwise, as the rashhealer had done, saying quietly, "Oh Lord, if that is Thou holy will, let the pain be eased".' (ERA II 40, 76/8 (15) < Pöide parish - A. Lesk (1925)). Tiitsu Seiu used to kneel when mixing the potion, just as when saying prayers in church. Bareheaded posture and invocations to the Father, the Son and the Holy Spirit were also used by Suri, one of the best known ever witch doctors of southern Estonia, at the beginning of his healing ritual (q.v. Kõivupuu 1995, 239). The famous contemporary witch doctor Laine Roht mixes her remedies in the back room of her house. She recites her spells and prayers over the potions at the spot where she was born and where her cradle once stood. Her choice of that very spot was induced by her family heritage which says that the local midwife saw the sign of a doctor on her forehead. Laine Roht usually relieves the uneasiness and tension of the patients with jokes. Jokes and allusions to people who live in the neighbourhood of the patient help her generate the so-called common field, an atmosphere of confidence and ease. Although she receives several patients at a time, she tries to maintain an individual approach and close personal contacts. Patients write down their complaints in a registration book, and sign their names on the bottles or jars that they have brought for remedies. Magical incantations and preparation of remedies in the back room is individual - the healer reads what has been written in the book, concentrates her mind and reads prayers over the remedies, one by one. Incantations at the process of preparing remedies is not unlike the usual silent praying. Having recited the spells, she caps the bottle or shuts the bag at once, and opens it only in the reception room where the patients try the remedies according to the healer's prescriptions. Naturally, the situation of prayer contains general human patterns of acting that could be recreated subconsciously, without taking any direct examples. 
Anyway, a healer must acquire certain minimum knowledge of the tradition (q.v. Chistov 1987), which is freely supplemented by him (or her) with the experiences, beliefs and knowledge of his own and of the members of his family. Thus, he shapes his own ritual model. Besides obligatory knowledge and decisions (diagnosing illnesses, choice of remedy, etc.) there were (are) optional or free decisions (such as settling the time and place of the rite), about which the healer has some basic knowledge, but at the same time he is free enough to make an independent choice. Therefore, the healing rite may be postponed until the following Thursday, full moon, auspicious wind or other weather conditions, or until the healer finds an assistant of required qualities. The decision, which of the circumstances must definitely be present and which may be omitted without impairing the efficacy of the healing procedure, is made by the healer individually. When solving a critical situation, a witch doctor chooses those explanations and methods of healing that he considers most suitable in this particular case. In most cases, however, the solution is stereotype (they often follow the laws of the tradition, in other words, established beliefs and ritual elements are more likely to be chosen at specific occasions than individual creative elements of the healer). Thus, Thursdays and other even days are more prone to be appointed, since they have the required belief background. As a rule, it is the witch doctor's choice whether he makes use of the personal, more improvisational part of his knowledge, or the one prescribed by traditional norms.

In oral tradition there are belief accounts stressing that learning the spells must pass silently. The Master recites incantations audibly, but the disciple can repeat them only quietly. Mentally one may repeat them as often as one needs to memorize them. It is also allowed to write the spells down and to read them until they are learned by heart. Very interesting are the belief accounts stating that the recipient of the knowledge (it concerns principally incantations) must not cross running water, or several watercourses.

\section{The Healer and Ethical Principles}

The successor was expected to have certain qualities and power. If they were not present, teaching could be interrupted. From characteristic qualities, keeping one's word, general talent, skilful hands, lack of such qualities as sudden fits of anger or bearing a grudge against somebody for a long time, love for animal and children and attentiveness were stressed. Very often a supposed successor has been denied magic formulas or details of a healing ritual because of an unpleasant disposition (cruel, drunkard, of a weak character). "He did not transmit the formulas to his sister, said that she was not a good person." (Witch E RKM II 397, 230/1 (1) < Võnnu) "He who knows the words must be a calm and quiet person."

In the transmission of magic formulas there were several rules: for example, they were not to be taught so that the disciple had to cross a body of water (or three) on his/her way home - the magic spell loses its power. Also, the disciple was not allowed to repeat them in a loud voice. The possessor of the words was not to ask any reward for healing or teaching and he/she had to have faith in his/her powers and spells. The same requirements applied to the successor. For example: "Grandfather had his own faith. (My) father said: "Father, teach me your knowledge." He said: "No, you do not have your faith. I have such a faith." He believed it himself and other people believed in him. It was as if he hypnotized." 
"My mother has offered it several times. "Write it down, it won't do any harm." I have written it down and then lost it," a successor of Witch $\mathrm{C}$ admits. The refusal to accept the heritage can be a result of one's youth: often the profession of a witch doctor and the resultant somewhat marginal role in the village community, isolation from ordinary norms, the heavy burden of resultant social relations and complicated ethical norms were feared. It was considered impossible to reveal some of the marginal knowledge: to predict somebody's death or calamities, etc. Such knowledge was like a sword with two edges: on the one hand ethical norms prohibited one to reveal the truth and on the other hand hiding the truth brought about open and secret accusations and even doubts in one's adequacy.

The studies could also be interrupted by the candidate, or he/she could give up the profession when he/she was not willing to receive the transmission, or when he/she felt that he/she could not manage.

The refusal to accept the transmission can be a result of the bad character of old witch doctors:

"My grandfather was Roosi Piidre, he lived in Võnnu. He healed all diseases. He promised to give all healing spells to his son. But he didn't want them because his father was a bad man."

It is also very usual that some of the successors never utilize the knowledge they have acquired. A healer with partial knowledge, however, could sometimes try to exploit his calling. The candidate could also be the son or the daughter-in-law of the family. Their candidacy could be revealed by certain presaging omens, events or prophecies coming true (e.g. certain signs at birth, etc.), after which the successor is accepted by the Master. Unbinding the "rope of wrath" (dissolving the ropelike company of sciara army worms) has been one of such indicators all over Estonia. Two excellent witch doctors from Maarja-Magdaleena were accepted by their predecessors after they had succeeded in the feat: after this sign the mother-in-law taught her knowledge to her daughter-in-law. Knowledge, especially spells, could also be acquired in dreams.

According to a belief (which is known world-wide), an old witch cannot die in peace until he (she) has transmitted his (her) knowledge. Many successors have used this fact to justify their acceptance of knowledge. Let us take again the stories about witch A in the parish of Võnnu. A man living in the same village has related the belief that is generally accepted in that region: 'It is said about them that they cannot lay down their lives. Poska Iida had it like that, too: Elmar left and went to Tartu, and found Iida behind the gates. She could not stay in the house, but had come out, and had died behind the gates. (RKM II 395, 358 (18) < Võnnu parish, Savimäe village - Kusta Anijärv, born 1903 (1986)).

The traditional heritage confirms that knowledge must be transmitted to a person who is younger than yourself, but not too young. "It is people in their thirties who have to be taught - people younger than that have weak lungs (i.e. breath), they are not able to bear the burden of uttering the magic formulas." Fully developed personalities were preferred. Some belief accounts recommend that men should transmit their knowledge to women, and vice versa. In reality, this was a condition 
that was often overlooked. Knowledge was transmitted to anybody who was considered a proper vessel for it and who promised to make a good healer. Usually it happened at the age of about 50 -60 or 70 , sometimes earlier.

As the bearers of the tradition believe, a (witch) doctor must not be too old or have a serious disease, otherwise he has not enough power over the disease and he may accidentally transmit it to another person.

\section{Conclusion}

In 1987 B. G. Alver and T. Selberg found that, in contrast to the past, there has also been an increasing interest among folklorists in the whole traditional milieu, as is also the case in other studies of tradition (Alver \& Selberg 1987a:68).

As a rule, esoteric knowledge has been taught over a long period; here, an intuitive, non-verbal, cognitive approach was especially highly appreciated. These requirements gave considerable advantages to those successors who belonged to the same family, who had the opportunity to stay in the natural environment with the transmitter of tradition for a long time, to follow and observe him in various situations. The period of mutual examination was also longer and more fruitful.

Probably every healer of the older generation has come into contact with the traditional representatives of folk medicine, whether Estonian or not. Yet, the willingness and capacity to acquire knowledge from them vary from person to person. It seems that studying from books, exchange of knowledge with each other, and with representatives of the traditional folk medicine of other nations are the prevalent methods. Spiritual or esoteric knowledge is realized and disseminated through mediators. These are used in (healing) rites. To the actual knowledge of traditional healing and diagnosing belongs a great deal of secondary knowledge, incl. pragmatic beliefs that he can use in building up his rite. Knowledge is transmitted through open verbal communication. However, that is not the only way of transmission of traditional heritage. Very important is observation, watching your Master, but also other ways of non-verbal communication. An unequalled advantage was (and still is) growing up within the tradition. In this way professional skills, techniques, conventions, even the traditional way of life and values were picked up unconsciously. From the earliest childhood an individual adapted himself to his family and kindred, but also with the social role that was appointed for him or that he had chosen. Today, family has still a very important role to play in the development of a witch doctor. But there are far more of those who become healers without having the traditional background or connection with folk medicine. More and more people are becoming healers after going through some training course, whether at their own will or encouraged by the approval of a witch doctor. For the most part, their knowledge is obtained outside the family circle.

Anyway, here we come into contact with the issue of freedom and inevitability. Relatively free is the choice of the place and time and means of healing/witchcraft. In a healing ritual as a whole, the witch doctor depends on the expectations of the patient, on what they are ready to accept. Therefore, witch doctors often adapt their vocabulary and rites, using words, expressions and phenomena that are currently in vogue. 
An Estonian journalist said in an interview that famous people do not belong to themselves. This applies also to witches. They belong to bearers of tradition who make up their own version about the life and death of the witches.

\section{References}

Aarma, Gunnar 1995. Joogaraamat. Tallinn.

Aarma, Gunnar 1996. Seda ei tea igaüks. Tallinn.

Alver, Bente Gullveig \& Selberg, Torunn 1987a. Folk medicine as part of a larger concept complex. ARV. Scandinavian Yearbook of Folklore, vol. 43.

Alver, Bente Gullveig \& Selberg, Torunn 1987b. Trends in Research on Folk Medicine in the Nordic Countries. Ethnologia Scandinavica, vol. 22.

Alver, Bente Gullveig 1990. Creating the Source Through Folkloristic Fieldwork. FFC 246.

Helsinki.

Ariste, Paul 1936. Eesti Kirjandus. I.

Hoffmann-Krayer \& Bächtold-Stäubli 1930/1. Handwörterbuch des deutsches Aberglaubens.

Hoppál, Mihály 1996. Shamanism in Postmodern Age. Folklore. An Electronic Journal, 2. Tartu.

Korb, Anu \& Peebo, Kadri 1995. Siin Siberi maa peal kasvanud. Eesti asundused I. Tartu.

Kõiva, M. 1989. Aleksei Lesest ehk Tiitsu Seiust. Paar sammukest eesti kirjanduse uurimise teed, XII. Tallinn.

Kõiva, M. 1990. Estonskije zagovory. Klassifikatsija i zhanrovye osobennosti. Dissertatsija na soiskanie kandidata filologicheskikh nauk. Tallinn.

Kõiva, Mare 1995. From Incantation to Rite. Kõiva, M. \& Vassiljeva, K. (eds.). Folk Belief Today. Tartu.

Maaema mess 1996. Tallinn.

Mansikka, V. J. 1928. Lithauische Zaubersprüche. FFC 87. Helsinki.

Mirtem, Valev 1994. Sensitiivne Eesti. Tallinn.

Paju, Aili 1995. Aed ja mets kui apteek. Tallinn.

Pócs, Éva 1985. Magyar ráolvasások. II. Budapest.

Price-Williams, D. R. 1973. A Case Study of Ideas Concerning Disease Among the Tiv.

Rørbye, Birgitte 1983. Peder Kragsig. Parantamisen taitajat. Vaasa.

Skinner, E. P. Peoples and Culture of Africa: An Anthropological Reader. New York.

Smirnov, J. 1988. Peredacha, ispolneniei zapominanie zagovorov v Russkom Severe.

Etnolingvistika teksta. Semiotika malykh form folklora. Moskva.

Vigala Sass /Aleksander Heintalu/ 1992. Minu raviraamat I. Kuidas ma ravin rahvast. Tallinn.

Viilma, Luule 1994. Ellujäämise õpetus, I. Tallinn.

Viilma, Luule 1996. Ellujäämise õpetus, II. Tallinn. 